\title{
Ankara İli'nde Bisiklet Kullanan Bireylerin Karşılaştıkları Sorunlar ve Çözüm Önerileri
}

\author{
The Problems Faced by Individuals Riding Bicycle \\ in Ankara and the Solution Offers
}

\section{Senem ÇEYIZ* \\ Funda KOÇAK ${ }^{* *}$}

Öz: Her geçen gün kalabalıklaşan kentlerde bisiklet kullanımının yaygınlaşması önemlidir. Dolayısıyla kent yaşamında bisiklet kullanımının önündeki çeşitli engellerin belirlenmesi yerel ve merkezi yönetimlere yol gösterici nitelikte olacaktır. Çalışmanın amacı Ankara ilinde bisiklet kullanan bireylerin karşılaştıkları sorunları ortaya koymak ve bu sorunların ortadan kaldırılmasına yönelik çözüm önerileri sunmaktır. Çalışmada nitel araştırma desenlerinden durum çalışması yöntemi kullanılmıştır. Çalışmanın örneklemini, amaçlı örnekleme yöntemine göre belirlenmiş, Ankara'da bisiklet kullanan toplulukların kurucuları konumunda 3 kadın, 9 erkek olmak üzere toplam 12 bisiklet kullanıcısı oluşturmaktadır. Türkiye genelinde kadın bisiklet kullanıcı sayısının erkeklere oranla daha az olması (Ardahan \& Mert 2014), örneklem grubuna da yansımıştır. Veriler, nitel araştırma yöntemi doğrultusunda gerçekleştirilen bireysel görüşmeler yoluyla toplanmıştır. Katılımcılar başlıca sorunları fiziki alt yapı yetersizliği, kent trafiğindeki sorunlar, sosyo-kültürel sorunlar ve yasal sorunlar olarak ifade etmiş, sorunların çözümü noktasında ise; bisikletli ulaşım için fiziki alt yapı uygulamalarının gerçekleştirilmesi, yerel yönetimlerin bisiklet kültürünün oluşturulması konusunda aktif rol alması, kurum ve kuruluşların işbirliği ile bisiklet konusunda farkındalık çalışmaları yapılması ve yasaların işlevsel duruma getirilmesini önermişlerdir.

Anahtar sözcükler: Bisiklet Kullanımı, Kent Yaşamı, Bisiklet Kültürü, Ankara

Abstract: It is important that the bicycle use spread in crowded cities. Thus it will be a guiding advice for the local and central governments, to determine the various obstacles in front of the bicycle use in urban life. The aim of this study is to reveal the problems faced by individuals using bicycles in Ankara and to offer solutions to eliminate these problems. The case study method, one of the qualitative research designs, was employed in this study. Based on the purposive sampling method, the sample of the study consisted of 12 cyclists ( 3 females and 9 males) founding the cycling communities in Ankara. The fact that the number of female cyclists is less than male cyclists in Turkey (Ardahan \& Mert 2014), is reflected in the sample group. Data were collected through individual interviews carried out in accordance with the qualitative research methods. Participants determined the lack of physical infrastructure, problems in urban traffic, socio-cultural issues and legal issues as main problems; and offered carrying out physical infrastructure for bicycle transportation, local governments' taking active roles in forming bicycle culture, awareness activities being done with the cooperation of institutions and organizations and bringing the laws to functional status, as their solutions.

Keywords: Bicycle Use, Urban Life, Bicycle Culture, Ankara

\footnotetext{
*Arş. Gör., Ankara Üniversitesi, Spor Bilimleri Fakültesi, Spor Yöneticiliği Bölümü, Ankara. ceyizsenem@hotmail.com **Arş. Gör. Dr., Ankara Üniversitesi, Spor Bilimleri Fakültesi, Spor Yöneticiliği Bölümü, Ankara. fkocak@ankara.edu.tr
} 
“19. yüzyılın başlamaslyla birlikte Avrupa'da önce üst sinıfin kullanmaya başladığı bisiklet, çok geçmeden Osmanlı'da da ülkede yaşayan Levantenler aracılığıyla yaygınlaşmıştır" (Süme \& Özsoy 2010). İthal edilerek ülkeye getirilen bisiklet, sadece Levantenlerin kullandığı bir araç olmaktan ziyade, zamanla halk arasında da yaygınlaşmıştır. Cumhuriyet döneminde ise bisiklet ulaşımı hızlandıran bir araç olarak kullanılmıştır (Süme \& Özsoy 2010).

"Yetmişli yıllarda yaşanan petrol krizleri ardından kent içi ulaşımda yeniden tanımlanan öncelikler, politikalar ve stratejiler, bisiklet kullanımında yeni bir dönemi başlatmıştır. Çevreye duyarlı ulaşım politikaları ile sinırl ve kirletici petrol enerjisini az tüketmeye yönelik hedefler, kent içi ulaşımda bisiklet kullanımının yeniden keşfedilmesini sağlamıştır" (Mert \& Öcalır 2010).

Bugün yaşadığımız her ortamda bisiklet görünür bir araçtır. Hiçbir zaman modası geçmeyen bu ulaşım ve eğlence aracının kullanım yaygınlığı oldukça fazladır. İnsanlar bisikleti kimi zaman ulaşım için kullanırken kimi zaman da rekreasyon amaçlı, turizm amaçlı seyahat ve iş için kullanmaktadır. Bisiklet kullanımının yaygınlaştırılması; toplum sağlığı, beşeri ilişkilerin ve spor bilincinin gelişmesi, çevre ve hava kirliliğinin azaltılması, enerji tasarrufu, trafik yoğunluğunun azaltılması, ulaşım kolaylığı gibi konularda önemli derecede olumlu bir etkiye sahiptir. Ulaşım için düzenli olarak bisiklet kullanan bireylerin tıbbi risk faktörlerinin daha düşük olduğu görülmektedir (Huy, Becker, Gomolinsky, Klein \& Thiel 2008).

Bireyleri bisiklet kullanmaya motive eden faktörler; doğayı, hızı, zor koşullarla mücadeleyi deneyimleme, taktir edilme, fark edilme, kendini gösterme, ekolojik duyarlılık, farkındalık, ulaşım, fiziksel aktivite ve sağlık, sosyalleşme, bireyin kendiyle rekabeti, uzaklaşma ve dinlenme, örnek olma, özgürlük hissi, özgürce yiyebilme ve kilo kontrolü, coğrafik uygunluk olarak belirlenmiştir (Ardahan \& Mert 2014). Ayrıca açık alan rekreasyon faaliyetleri olan bisiklet ve doğa yürüyüşleri gibi etkinliklere katılan bireyler; kendilerini daha mutlu, sağlıklı ve güçlü, rahatlamış/tazelenmiş hissetmek, kendilerine olan güvenin artması, çevre bilinci kazanmak, daha verimli çalışabilmek, kendilerini daha önemli hissetmek gibi faydalar elde ettiklerini ifade etmiştir (Ardahan \& Lapa 2011). Bisiklet kullanımı bir toplum için gerekli olan bireyler arasındaki sosyal yakınlaşmayı artıran, insan ilişkilerinin daha empatik bir çerçevede şekillenmesini sağlayan bir ulaşım şeklidir (İyinam \& İyinam 1999).

Kullanım alanı çok geniş olan bu aracın günlük yaşamda sağladığı avantajlarının yanı sıra bisiklet sürücülerinin yaşadığg sorunlar da günden güne büyümektedir. Bisiklet sürücülerinin beklentilerinin karşılanması konusundaki yaygınlık, bütün ülkelerde homojen olmadığı gibi ülkemizde de bu sorun mevcut durumdadır. Ülkemizin iklim ve coğrafi koşulları bisikletli ulaşım konusunda oldukça gelişmiş olan birçok ülkeye göre engel teşkil etmeyecek avantajlara sahiptir. Ancak ülkemizde motorlu araçların kullanımı için yapılan altyapı çalışmalarına oranla bisiklet kullanımını artırmaya yönelik çalışmaların yetersizliği bugün tartışma konusu haline gelmiştir. Oysa dünya çapında; trafik sıkışıklı̆ğ, halk sağlığı veya yaşam kalitesi gibi kaygıların körüklediği toplumlar, bisiklet kullanım oranlarının artırılması ile giderek daha fazla ilgilenmektedir (Krizek, Poindexter, Barnes \& Mogush 2007).

"Bireylerin sosyal risklerden ve trafik risklerinden arındırılmış güvenlikli alanlarda iş, okul, arkadaş, komşu ve akraba ziyareti gibi günlük yaşamlarındaki rutinleri yerine getirebiliyor olması, bisiklete olan talebi artırmaktadır" (Ardahan \& Mert 2014). Bu durum bisiklet kullanımına yönelik engellerin ortadan kaldırılmasının gerekliliğini vurgular niteliktedir. Üzerine yoğunlaşıldığında tüm bu sorunların düşük maliyetlerle zaman içerisinde ortadan kaldırılabileceği düşünülmektedir. Örneğin bisiklet kullanımını yaygınlaştıran uygulamalardan biri olan bisiklet 
kiralama sistemi, kentsel alanlarda bir toplu taşıma biçimi olarak bisikleti kullanan bir istasyondur (Lin, Yang \& Chang 2013). Bu sistem dünya çapında kasaba ve şehirlerde giderek daha popüler hale gelmekte olup, yoğun kent ortamında gezinmek ve ulaşımı sağlamak açısından ucuz, verimli ve sağlıklı görülmektedir (O’brien, Cheshire \& Batty 2013).

Bisiklet daha sürdürülebilir kentsel ulaşım sağlaması açısından önemli bir rol oynar. Gerçekten önemli olan engeller ise bireylerin kafasında olan yaşam tarzı seçimleri ile bu seçimleri şekillendiren bilim adamları, teknisyenler, bürokratlar ve politikacılardır (Tomlinson 2003).

Yurt içinde ve yurt dışında konu ile ilgili yapılmış olan çalışmalara bakıldığında; yerel ve genel yönetim birimlerinin bisiklet ulaşımı için gerekli adımları atması durumunda ve insanlar arasında oluşturulabilecek bir bisiklet kültürü ile bisiklet ulaşımının Türkiye'de de cazip hale geleceği değerlendirilmiştir (Akay 2006). Bisiklet kullanımının arttırılabilmesi için en temel şart insanların bisiklet kullanabilecekleri ortamın yaratılmasıdır. Bisikletliler için yeni yollar yapılması, mevcut yollarda bisikletliler için alanlar oluşturulması ve bisiklet altyapısının geliştirilmesi en önemli önceliktir (Elbeyli 2012). Yol bozukluğunun artmasıyla bisiklet ve sürücünün maruz kaldığı titreşim büyüklüğü ve frekansı bozulan solunum paterni, artan kas tonusu gibi, vücut fonksiyonları üzerinde bazı olumsuz etkileri olduğu görülmüştür (Arpınar-Avşar 2009).

Trafikte güvende olmama endişesi her gün bisiklet süren ve ara sıra bisiklet süren, kadın kullanıcıların bisiklet kullanımını engelleyen en önemli etkendir (Broache 2012). Bisiklet kullanımının kamu tarafından kabul edilebilirliğini geliştirmeye ve kamusal normları değiştirmeye ihtiyaç vardır. Bisiklete binmek, özel kıyafetler ya da pahalı ekipmanlara ihtiyaç olmaksızın hemen hemen herkes tarafından gerçekleştirilebilen bir günlük aktivitedir (Daley \& Rissel 2011). Ulaşım amaçlı bisiklet kullanan bireylerin trafik kurallarını ihlal etme nedenlerinin başında kötü alt yapı tasarımı, ardından motorlu araç trafiğinin hızı ve diğer sürücülerin trafikteki davranışları gelmektedir. Bisikletlilerin varış noktalarına güvenli ve zamanında ulaşmalarını ve trafik kurallarına uymayı teşvik edecek bir ulaşım ağı gerekmektedir (Shaw, Poulos, Hatfield \& Rissel 2014). Bisiklet park alanlarının ve iş yerinde duş imkanının bulunması işe geliş-gidişlerde bisiklet kullanım oranını artıran faktörlerdir (Buehler 2012).

$\mathrm{Bu}$ çalışmanın amacı Ankara ilinde bisiklet kullanan bireylerin karşılaştıkları sorunları ortaya koymak ve bisiklet kullanıcılarının önündeki engellerin ortadan kaldırılmasına yönelik çeşitli çözüm önerileri sunmaktır.

\section{Yöntem}

Çalışmada nitel araştırma desenlerinden durum çalışması yöntemi kullanılmıştır. Araştırmada, bisiklet kullanan bireylerin deneyimlerine görüşmeler yoluyla daha derinlemesine ulaşılabileceği düşünüldüğünden, verileri toplamada, nitel araştırma tekniklerinden "yart-yapılandırılmış görüşme" tekniği kullanılmıştır.

\section{Örneklem}

Araştırma amacına uygun olduğu düşünülen örneklem grubunun araştırmacı tarafindan seçilmesini ifade eden amaçlı örnekleme, nitel araştırmalarda kullanılan yaygın olasılıksız örnekleme tekniklerindendir (Marshall \& Rossman 2006). Bu anlamda Ankara'da kent yaşamında bisiklet kullanan bireylerin sorunlarını belirlemek için gündelik yaşamında aktif olarak bisiklet kullanan bireyler seçilmiştir. Ayrıca seçilen bireyler, gruplar halinde bisiklet kullanan toplulukların kurucuları ve liderleri konumundaki bireylerdir. Katılımcıların bu konumu, kurucusu oldukları grubun diğer üyelerinin de, kent yaşamında bisiklet kullanırken karşılaştıkları sorunlar konusunda bilgi ve tecrübe sahibi oldukları anlamına gelmektedir. Katılımcıların bu tecrübelerini 
çalışmaya yansitabilecekleri düşünülmüştür. Çalışmanın örneklemi, amaçlı örnekleme yöntemlerinden maksimum çeşitlilik örneklemesine göre belirlenmiştir. Patton'a göre, maksimum çeşitlilik gösteren küçük örneklem; örnekleme dahil her durumun kendine özgü boyutlarını ayrıntılı şekilde tanımlar ve büyük ölçüde heterojenlik gösteren durumlar arasında ortaya çıkabilecek ortak temalar ve bunların değerlerini ortaya çıkarır (Akt. Yıldırım \& Şimşek 2013). Araştırmaya katılan bisiklet kullanıcıları, ikamet ettikleri semtler doğrultusunda, Ankara kırsalı, kent merkezi ve varoşlarda gündelik yaşamlarında, zaman zaman kurucuları oldukları gruplarla, zaman zaman bireysel olarak bisiklet sürmektedirler. Dolayısıyla katılımcılar kentin farklı bölümlerini temsilen farklı bisiklet kullanım tecrübelerine sahip bireylerdir. Ankara'da kent yaşamında bireysel olarak bisiklet kullanan ve aynı zamanda çeşitli amaçlarla gruplar halinde bisiklet kullanan 9 grup, topluluk ve oluşumun kurucuları ve liderleri konumunda olan yaşları 22 ile 55 arasında değişen 3 kadın 9 erkek olmak üzere 12 katılımcı ile bireysel görüşmeler yapılmıştır. Katılımcılar Ankara ilinde kent yaşamında 2 ile 12 yıl arasında değişen süredir bisiklet kullanan bireylerdir. Katılımcıların mesleklerine bakıldığında, 1 emekli, 1 kamu çalışanı, 4 serbest meslek sahibi, 2 akademisyen, 1 eğitmen ve 1 öğretmen şeklindedir. Ayrıca 1 işsiz ve 1 öğrenci bisiklet kullanıcısı da araştırmanın katılımcıları arasında yer almaktadır. Katılımcıların öğrenim durumlarına bakıldığında, 1 lise mezunu, 1 üniversite öğrencisi, 1 ön lisans mezunu, 5 lisans mezunu, 4 katılımcının ise lisansüstü mezunu olduğu görülmektedir.

\section{Veri Toplama Araçları}

Araştırmada 12 bireysel görüşme yapılmış ve araştırmada kullanılan veriler bu görüşmeler yoluyla elde edilmiştir. Ayrıca araştırmada, bireysel görüşmelerin yapıldığı katılımcılardan görüşmelerde, sosyo-demografik özelliklerini belirlemeye yönelik soruların yer aldığı Kişisel Bilgi Formu doldurmaları istenmiştir. Araştırmanın amacı ve araştırmanın kuramsal çerçevesi doğrultusunda görüşmelerde katılımcılara, kent yaşamında bisiklet kullanma nedenlerine, bisiklet kullanırken karşılaştıkları sorunlara, bisiklet kullanmanın avantajlarına ve dezavantajlarına, kent trafiğinde bisiklet kullanırken kendilerini güvende hissedip hissetmediklerine ve sorunların çözümü için yapılabileceklere ilişkin sorular yöneltilmiştir.

Bireysel görüşmeler 10-22 dakika arasında sürmüştür. Ayrıca görüşmelerde, katılımcılardan izin alınarak ses kayıt cihazı kullanılmıştır.

\section{Veri analizi}

Verilerin analizinde içerik analizi yöntemi kullanılmıştır (Yıldırım \& Şimşek 2013). Bu analiz tekniği kapsamında, çalışmadan elde edilen veriler yazar tarafindan incelenerek kodlar oluşturulmuş ve bu kodlar belirli temalar altında sınıflandırılmıştır. Bu analiz sürecinin aşamaları aşağıda verilmiştir.

\section{Açık kodlama}

Görüşme metinleri bilgisayar ortamına aktarılarak ve araştırmacılar tarafindan araştırma problemi kapsamında önemli ve ilginç bulunan kodlar belirlenmiştir. Kodlama sürecinde araştırmacının, araştırma sorularını ya da araştırmanın kavramsal çerçevesini dikkate alması ve bu çerçevede verilerin içinde ne aradığının sürekli farkında olması gerekmektedir (Yıldırım \& Şimşek 2013). Bu doğrultuda, veri analizinin ilk aşaması olarak kodlamalar yapılırken, elde edilen verilerle beraber araştırmanın kuramsal çerçevesi ve bu çerçeve bağlamında sorulan sorular da dikkate alınarak bir kod listesi oluşturulmuştur. Elde edilen verilerde bu kodlardan farklı kodlar bulunduğunda bunlar da kod listesine eklenmiştir. 


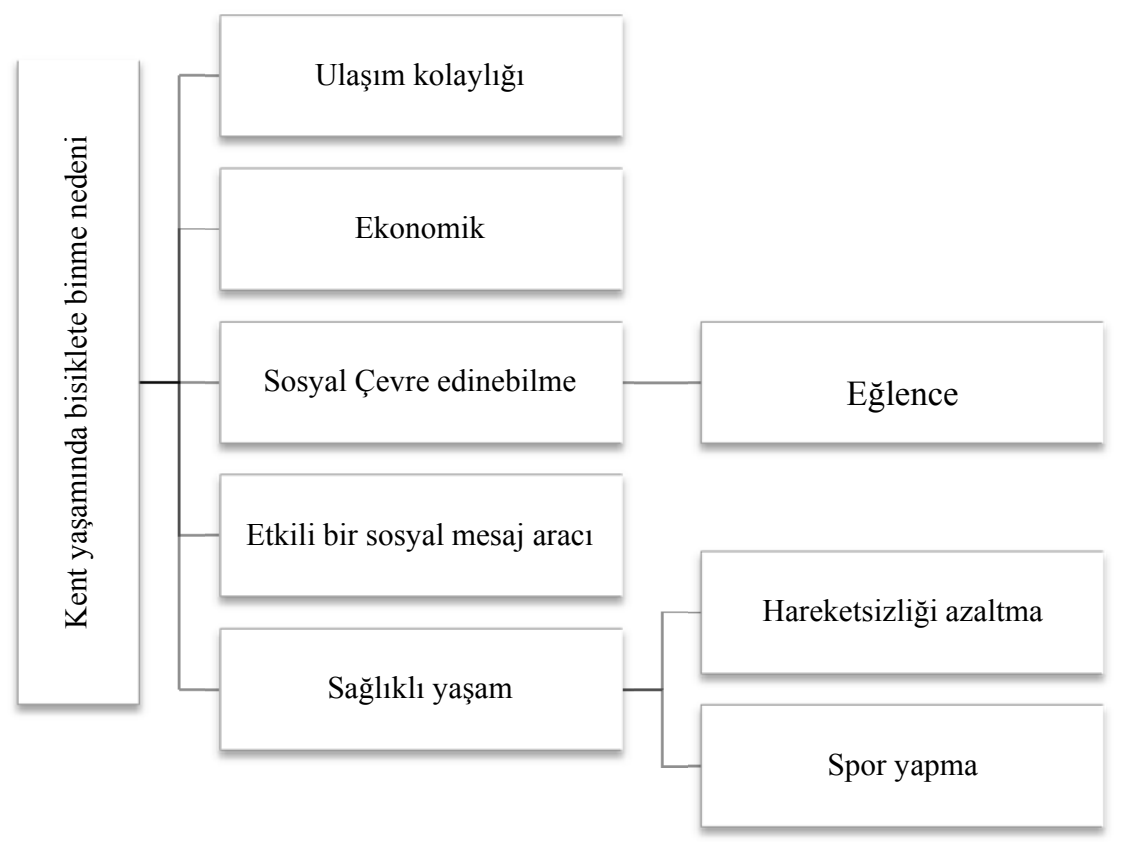

Fig. 1. Kent Yaşamında Bisiklete Binme Nedenleri

\section{Tematik kodlama}

Elde dilen verilerin kodlanmasından sonraki aşama, birbiriyle ilişkili kodları bir araya getirebilecek temaların bulunmasıdır. Bu çalışmada, kodlanma sonucu ortaya çıkan kavramlar anlamlı bir tema altında toplanmaya çalışılırken, aynı kodlama sürecinde olduğu gibi hem çalışmanın kuramsal çerçevesi hem de veriler doğrultusunda temalar belirlenmiştir.

Araştırmacılardan birinin, Ankara'da farklı bisikletli gruplarla çeşitli etkinliklerde ya da gündelik yaşamında aktif olarak bisiklet kullanıcısı olması da çalışmanın yapıldığı sosyal bağlamın anlaşılmasında katkı sağlayan bir faktör olmuştur.

\section{Bulgular}

\section{Kent Yaşamında Bisiklete Binme Nedenleri}

Çalışmaya katılan bisiklet kullanıcıları farklı nedenlerle kent yaşamında bisiklet kullandıklarını ifade etmişlerdir. Ancak bisikletin Ankara'da kent yaşamında ulaşımı kolaylaştırdığı düşüncesi katılımcıların büyük bir çoğunluğunun hemfikir olduğu bir neden olarak ortaya çıkmıştır.

\section{Ulaşım Kolaylığı}

Araştırmaya katılan bisiklet kullanıcılarının çoğunluğu Ankara ilinde kent yaşamında bisiklete binme nedenlerinin, ulaşım kolaylığı sağlaması olduğunu ifade etmişlerdir. Buna sebep olarak ise motorlu araç trafiğinin özellikle kısa ve orta mesafelerde, daha çok zaman alması ve stres yüklü yolculuklar olması gösterilmiştir. Bazı katılımcılar görüşlerini şu şekilde ifade etmişlerdir.

[...] Toplu taşımadan daha hızlı yani şöyle, toplu taşımadan daha hızlı sonra kendimi daha özgür hissediyorum. İstediğim yere istediğim şekilde gidebiliyorum. İstersem yolu uzatarak istersem kestirmeden gidiyorum (Kemal).

\section{Ulaşımda özellikle kısa mesafelerde çok daha kısa bir zamanda istediğim}


yere daha kolay bir şekilde varabiliyorum. Aynı zamanda daha ĕglenerek varabiliyorum. Şehrin stresinden trafiğin stresinden uzak kallyorum bu sayede (Şemsi).

\section{Ekonomik Ulaşım}

Bisiklet kullanımının ekonomik bir harcama gerektirmemesi, katılımcıların kent ulaşımında bisiklet kullanmasının nedenleri arasındadır. Hilmi ve Oktay isimli katılımcılar düşüncelerini şu şekilde aktarmışlardır:

Bisiklete binmemin sebebi temelde ulaşım kaynakl. Mesafesine göre yani bu da yaklaşık gidiş mesafesi $10 \mathrm{~km}$ çapında olmak üzere gidiş mesafesinde daha hizll ve ucuz ve hatta ücretsiz seyahat için, bir alternatif olduğu için bisiklete biniyorum (Hilmi).

Hem ayrıa ekonomik katkısı da var tabi. Işyerinden eve gitmek için iki vasita değistirmem gerekiyor yani günde dört kez binmem gerekiyor. Dört kere iki sekiz aşağl yukarı sekiz lira gibi bir gider olması gerekirken ben bundan tasarruf etmiş oluyorum (Oktay).

\section{Ulaşım Sağlarken Sağlıkı Kalabilmek}

Ulaşım sağlarken bir taraftan da spor yapabilme imkânı doğduğu ve bisiklet kullanımının bazı sağlık problemlerinin aşılmasına yardımcı olduğu yönündeki katılımcı ifadeleri şu şekildedir:

[...] Aslında şöyle ben bir yaşam tarzı olarak bu tarzda doğa sporlarına hep ilgisi alakası olan bir insanım. Şehir yaşamında en basit en kolay yapabileceğimiz bu tarzda bir aktivite bisiklete binmekti (Hakan).

[...] Benim ilk bisiklete başlayışım zaten sağlık problemlerimden dolayıydl. Belimde dört tane fittğım vardı. Fitıklarımdan kurtulabilmek için bel kaslarımı güçlendirmem ve kilo vermem gerekliydi. Yaklaşık iki senedir belimle ilgili hiçbir problemim yok (Şemsi).

Ayrıca sosyal çevre edinme, gruplar halinde bisiklete binmenin keyifli olması da bisiklete binme nedenleri arasında gösterilmektedir:

[...] Tek başıma bisiklete binmeye başladım ve tabi böyle bir grup oluşması beni bisiklete binmeye daha da fazla iten neden oldu (Hakan).

\section{Bir Tema Olarak Bisiklet}

Katılımcılardan ikisi, bisikletin; kendileri için ulaşım, gezi, boş zaman değerlendirme gibi amaçlarını gerçekleştirdikleri bir araç olmanın yanı sıra, gerçekleştirdikleri çeşitli siyasi etkinliklerinde ve eylemlerinde bir tema olduğunu ifade etmişlerdir:

Aslında daha çok bir aktivistlik aracı benim için bisiklet. Hayvan besleme, eylemlere katılma, protesto gösterileri yapma, çeşitli sosyal sorunlara dikkat çekme, bu amaçla bisikletin önemli bir görünürlük sağladlğıı düşünüyorum. Bütün eylemlere de bisikletimle katıliyorum zaten. $O$ açıdan önemli bir eylemci aracı olarak geliyor bana (Çiçek).

[...] Bisiklet için de dersek biraz böyle siyasi etkinliklerimiz oluyor, daha tematik etkinlikler, bunlar için, dayanışma için yani o arkadaşlarla bisiklet aracılı̆̆ıyla gibi şeyler (Tolga). 
Yapılan analizler sonucunda katılımcıların kent yaşamında bisiklete binme nedenlerine ilişkin oluşturulan şema aşağıda gösterilmiştir.

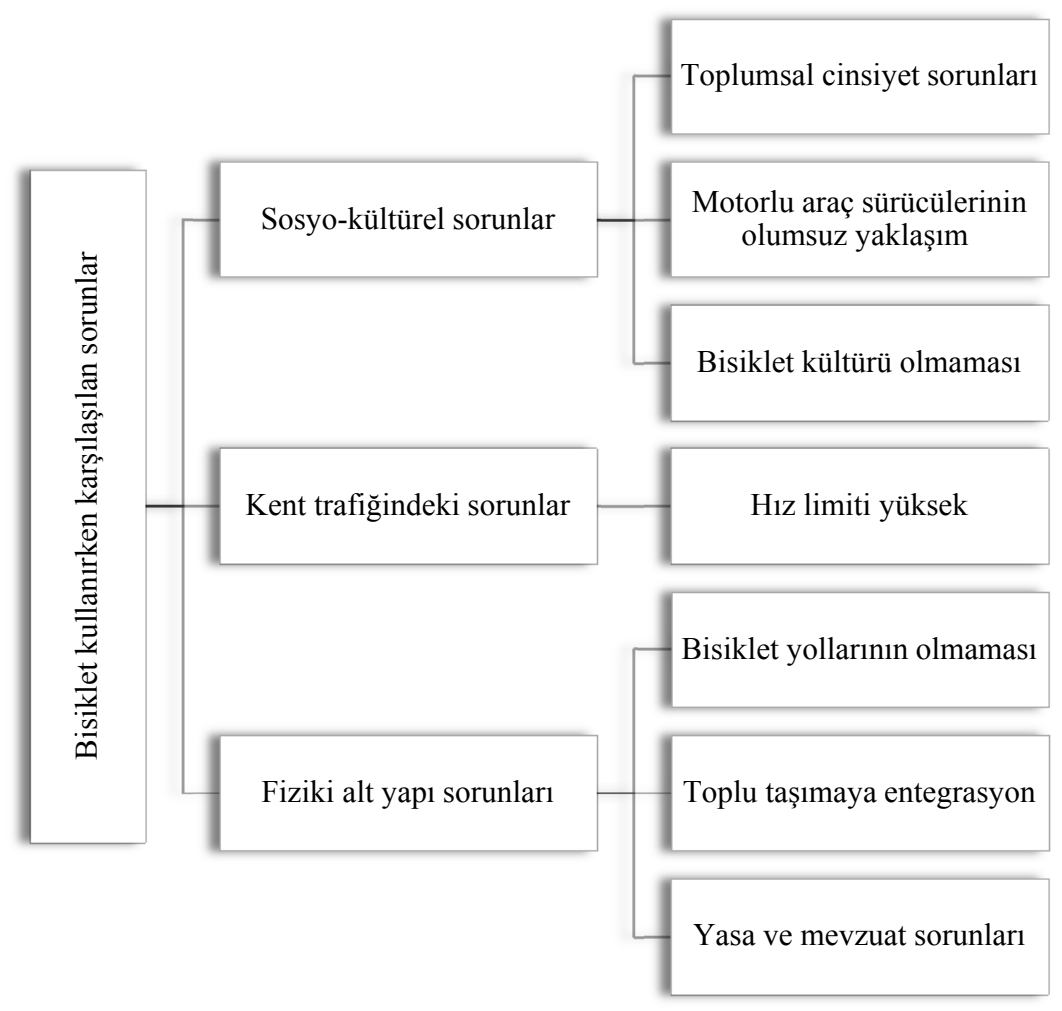

Fig. 2. Kent Yaşamında Bisiklet Kullanırken Karşılaşılan Sorunlar

\section{Kent Yaşamında Bisiklet Kullanırken Karşılaşılan Sorunlar}

Katılımcıların büyük bir çoğunluğu Ankara ilinde bisikletli olarak yaşadıkları sorunların kaynağını bisikletli ulaşımla ilgili fiziki alt yapı eksiklikleri olarak görmektedir.

Alt yapısal problemlerimiz de çok fazla. Yollar kesinlikle bisiklete göre değil. Mesela hani yolların yanında koruma şeridi var. Koruma şeritleri en azından bisikletlilere göre uyarlanabilir. Bisiklet yolu yapılmıyor, yapılması için uğraşıllyor ama bir türlü halen hayata geçirilmiş değil. Yani Avrupa'daki ülkeler gibi değiliz şu anda ne yazık ki. Ama hani en azından koruma şeritlerinin bile bisikletlilere göre uyarlanması birçok şeyi değiştirecektir ki bu sayede kaybettiğimiz dostlarımızın yanına yeni dostlarımızı da eklememiş oluruz belki (Şemsi).

[...] Bir de fiziki alt yapı yetersizlikleri evet öyle diyebilirim. En çok çukurlar, tümsekler ve mazgallar benim şikayet konum. Düz yolda giderken bir anda karşıma çıkan işte mazgal şey mazgal değil de şu logar kapaklarl, 10-15 cm dipte olanlar ya da çatlaklar, yarıklar, delikler, tümsekler. Bir anda çıklyor ama karşıya, yani yol halbuki gayet temiz giderken. Yine işte kalın çizgileri olan ve yol istikametinde olan mazgallar onlar da kâbusum (Çiçek).

Mevcut alt yapı sorunları arasında özellikle bisiklet yollarının olmaması önde gelen alt yapı eksikleri arasında ifade edilmiştir: 
En büyük sorun zaten bizim bisiklet yolumuzun olmaması. Ve hani binsek bile birçok trafikteki insanların bize sanki yollar hiç bizim değilmiş de, böyle daha çok olmamamı gerekiyormuş gibi davranmaları var... Altyapının hiç olmayışından dolayı insan bazen binmek bile istemiyor (Ali).

[...] Şimdi tabi alt yap sorunumuz var. Ankara bisiklet yolu olmayan çok nadir başkentlerden bir tanesi. İkinci sorunumuz da yolların fiziki durumları da çok kötü. Özellikle yolların ortası daha düzgün ve yolun kenarlarına nedense asfalt dökülürken pek bir itina gösterilmiyor. Her zaman için araba öncelikli tabi. Yani yolların fiziki durumu doğru değil ondan sonra mazgallar büyük bir sorun teşkil ediyor, yönleri tabi. Yönleri bir de yönleri doğru olsa bile asfaltta mazgalın seviyesi farkl oluyor. Ya fazla yüksek ya da alçak oluyor (Oktay).

[...] Bisiklet yolu alt yapısının olmaması kentte Ankara'da hiçbir şekilde. Buna yönelik bir ulaşım planı olmamış olması şu ana kadar, bir ulaşım planımız yok. Trafik çok yoğun ve hızlı birçok yerde. Yollarımızın içinde bulunduğu durum çok iyi değil. Çukurlar, mazgallar bisikletle ulaşımda tehlike yaratabilecek engeller var kent içinde, fiziki alt yapı anlaminda. IŞaret, bisikletlere yönelik yolla beraber onun çerçevesini oluşturacak alt yapı işaretler, tabelalar, ayrılmış yollardan, araba trafiğinden arındırılmış bisiklet yollarının olmaması. Ve bu konuda tabi kent bilincinin şu ana kadar yaratılamamış olması, bisikletin bir ulaşım aracı olarak Ankara'da henüz bir kabul görme durumu söz konusu değil (Oğuz).

\section{Motorlu Araç Sürücülerinin Olumsuz Yaklaşımları}

Kent trafiğinde bisiklet sürücülerinin sıklıkla karşılaştıkları sorunlardan birinin motorlu araç sürücülerinin olumsuz tavır ve davranışları olduğu katılımcıların birçoğu tarafından ifade edilmiştir. Bu sorunun bisikletli ölümlerine neden olabilecek boyutlara ulaşabildiğini belirtmişlerdir:

[...] Biz genellikle yolun, işte sarı çizginin sağını kullanmaya özen gösteriyoruz; trafiğin akışını engellemeyelim diye. Ama işte bir de şöyle bir şey var tabi orda gittiğimiz sürece de araçlar bizi yok saylyor. $O$ da bizim can güvenliğimizi tehlikeye atıyor. O nedenle ben genellikle hizın çok fazla olmadiğı yerlerde săg şeridin tam ortasında gitmeyi tercih ediyorum görünür olmak için (Oktay).

[...] Yolun üzerinde ilerlerken sürücülerin hani çok temel olacak ama davranışları bir kere ekside. Yani sen ona göre, sen kendini onlarla bir şekilde etkileşime sokarak, kendini onlara bir şekilde sevdirerek, böyle yukarı taşımaya çalışıyorsun. Normalde sana davranması gerekeni, sen böyle sevecenlikle hani göz temast ile el hareketi ile kurarak düzeltmeye çalışıyorsun (Namık).

Tabi alt yapı sorunları da var. Bir bisiklet yolu yok. Çok da mühim değil aslında, bisiklet yolu da, yollar yeter aslında yani şu anki yollar bile yeter de işte yolu paylaşmayı bilmeyince yetmiyor. Şey var yani Ankara'da en çok "motorize faşizm" diyor Ayşse de; yani güçlünün ne kadar güçlüysen o kadar çok hak alıyorsun. Yani altındaki araç ne kadar 
güçlüyse, trafiği kullanma hakkın o kadar yükseliyor. Aracın ne kadar büyükse; otobüsse, kamyonsa falan istediğin gibi yapıyorsun. Mesela cip taksiden daha büyük olduğu için, cipe binenlerin kullanım tarzı rahat yani. Giriyor yol vermiyor (Tolga).

\section{Bisikletin Toplu Taşımaya Entegre Edilmesi Gerekir}

Ankara yüzölçümü açısından bakıldığında oldukça büyük bir kenttir. Dolayısıyla özellikle ilçeler arasındaki ulaşımı bisikletle sağlamak çok zaman alacağından, gezi amaçlı kullanımlar d1şında mümkün olmamaktadır. Bu bağlamda mevcut sorunlar arasında bisikletin toplu taşımaya entegrasyonunun da önem teşkil eden bir konu olduğu katılımcılar tarafından ifade edilmiştir.

Bisikletin yaşamımıza dahil edebilmesi için yaşantımıza tam entegrasyonunun sağlanması lâzım. Bir kere toplu taşımada büyük eksiklik var. Mesela metrodan çıktınız; yurt dışında nasıl kullanılıyor; metrodan çıkıyorsunuz bisiklet park alanları var. Park alanından bisikletinizi alıyorsunuz veya park edebiliyorsunuz. Metroya binip yolunuza devam edip, tekrar geldiğinizde devam edebiliyorsunuz (Yasemin).

Mesela ben bisikletimi hiç metroya atarak gideceğim yere gitmeyi düşünmüyorum, düşünemiyorum çünkü bu benim için bir oto kontrol. Şunu düşünüyorum metrodaki güvenlik görevlileriyle tartışacă̆ım. Örnek olarak bu benim için bir zorluk. Psikolojik bir zorluk bu. Çünkü daha önce yaşanan tartışmalardan olumsuzluklardan kaynaklı olarak verdiğim bir tepki. Mesela bu benim için olumsuz bir durum Ankara'da ulaşımla ilgili, bisikletli ulaşımla ilgili toplu taşıma (Hilmi).

\section{Toplumsal Cinsiyet}

Ankara'da kent yaşamında bisiklet kullanımı ile ilgili fiziki sorunlar dışında sosyo-kültürel sorunlar da olduğu görülmektedir. Araştırmaya katılım gösteren üç kadın bisiklet sürücüsünün üçü de bu sorunları benzer şekilde ifade etmiştir.

Sosyo-kültürel olarak aslında Çankaya bölgesinde sıklıkla sürdüğüm için genelde garip bir şekilde algılanmiyorum ben. Fakat biraz dişarlya çıktığımda, daha ilçelerarası yollar aldığımda ya da ne diyeyim, bu kelimeleri hiç sevmiyorum, ama literatürde öyle geçiyorlar çoğunlukla. Sosyo-kültürel bakımdan düşük olan bölgeler diyeyim ama sevmediğim kelimeler dediğim gibi; oralarda seyrederken bazen ilginç tepkiler alabiliyorum. Ya "Bu yaşta bisiklete mi biniyorsun teyze" oluyor ya da bazen hafif taciz noktasında şeylerle de karşılaşabiliyorum (Çiçek).

[...] Zorluklarla karşılaşıyoruz. Öncelikle mesela kadın olmam bir kere birinci zorluk bundan ötürü yani özellikle bu kırsal kesimlerde daha ilçelerde kadınlara yönelik laflar atılması beni çok üzüyor (Gül).

[...] Bir kere fark edilmemek, trafikte giderken fark edilmemek. Tabi ki bu size dair de, sizden kaynakl şeyler de var; kültürel olarak da farklı şeyler var. Nelerdir bunlar, mesela kişisel olarak bayan olmanın verdiği bir dezavantaj da var. Mesela yolda giderken tacize de uğrayabiliyorsunuz. Bisiklet üstünde giden bir kadın gördükleri zaman inanılmaz şaşlrlyorlar, kaldı ki siz bir de spor klyafet giyip, antrenman şeklinde gidi- 
yorsanız, kask takıyorsanız, daha çok dikkatleri üstünüze çekiyorsunuz. Bu tabi ki ülkemizde bisiklet kültürünün olmayışlyla alakalı (Yasemin).

Yapılan analizler sonucunda katılımcıların kent yaşamında bisiklet kullanırken karşılaştıkları sorunlara ilişkin oluşturulan şema aşağıda gösterilmiştir.

\section{Kent Yaşamında Bisiklet Kullanmanın Avantajları}

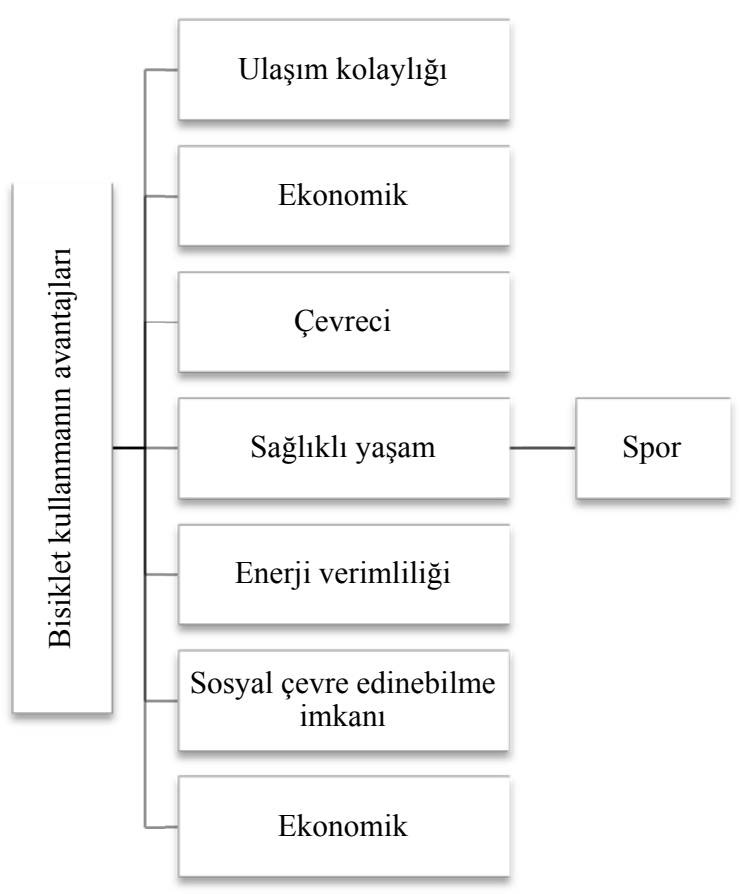

Fig. 3. Kent Yaşamında Bisiklet Kullanmanın Avantajları
Katılımcıların Ankara'da kent yaşaminda bisiklet kullanmanın avantajlarına verdikleri yanıtlar, neden bisiklet kullandıkları sorusuna verdikleri yanttlarla örtüşür nitelikte olduğu görülmektedir. Başlica avantajlardan birinin ulaşım kolaylığı olduğu farklı katılımclar tarafindan ifade edilmiştir:

[...] Ĕger merkezde işiniz varsa, merkezde çalışlyorsanız işe gidip gelirken toplu taşım ya da özel araçlar oldukça yavaş seyrediyorlar. Bir tane örnek verecek olursam, Eymir dönüşünde TRT'den çıkış yapıyoruz. Orda bir belediye otobüsü ile mesela durakta gördügümüz bir belediye otobüsü. Plakasını alıyoruz ondan sonra baklyoruz Kizllay'a geliyor. Biz de Kizllay'a geliyoruz. Şimdi genellikle o otobüsten 10-15 dakika önce gelmiş oluyoruz. Çünkü o duraklarda durmak zorunda. Trafik sıkıştı mi, önü bloke edilmişse o önünün açılmasını beklemek zorunda. Oysa biz să̆ şeritten sarı çizginin sağından akıp gidebiliyoruz. Öyle bir avantajımız var (Oktay).

[...] Trafik olduğu zaman rahatlıkla her yere gidilebiliyor; yakın yerler özellikle. Ulaşım kolaylı̆̆ sağlıyor (Ali).

[...] Trafik olduğu zaman rahatlıkla her yere gidilebiliyor; yakın yerler özellikle. Ulaşım kolaylı̆̆ să̆lıyor (Ali).

[...] Özellikle mesai saatlerinde o tıkanmıs trafiğin arasında tereyağından kıl çekercesine gidip gelmek gerçekten çok hoşuma gidiyor. İnanılmaz keyifli (Çiçek).

[...] Benim evim Kızılay'a yaklaşık altı kilometre. Trafiğin yoğun olduğu zaman otobüsle kırk beş dakikada gittiğim yolu bisikletle ben on iki dakikada gidiyorum (Yasemin).

\section{Sosyal Etkileşim Sağlar}

Katılımcılar bisiklet aracılığıyla sosyal çevre edindiklerini ifade etmişlerdir: Arkadaşlarımızla bir şey yapacağımızda bize daha çok keyif veriyor 
bisikletin olması (Ali).

[...] Bisiklet aracılı̆̆ıyla yeni insanlar tanıyorsun o kısmı da var tabi onu da söylemek lazım. Sosyalleşme imkanı mı diyelim. Yeni insanlar, güzel insanlar, böyle dayanı̧̧ma içinde olabileceğin insanlar tanıyorsun. Yeni bir çevre ediniyorsun, yeni bir çevreye girmiş oluyorsun (Tolga).

\section{Bisiklet Enerji Verimliliğine Katkı Sağlar}

Enerji tüketimi göz önünde bulundurulduğunda bisiklet kullanımının yaygınlaşmasının, bu tüketimi azaltacağı ve ülke ekonomisine katkı sağlayacağı avantajlar arasında gösterilmiştir:

Biz enerjiye bă̆ımlı bir ülkeyiz. Politikalarımızın da bu yönde olması lazım. Daha çok para kazanabiliriz. Ekonomik olarak daha çok büyüyebiliriz ama bu bize enerji yaratan bir unsur değil. Paramızın olması enerjimizin de ilerde olacağı manasına gelmiyor. Birçok Avrupa ülkesinin verim dediğimiz konuya odaklanmasindaki temel etmen bu. Verim. Nüfusumuzun çok artmasına gerek yok ama mevcut paramı ve enerjimi, insan enerjimi en iyi şekilde ve doğru şekilde kullanayım. Bunun da zaten kanıtlanmış yönü de ve uygulanan yönü de bisikletli ulaşım; ĕger ulaşımda bu verimden bahsedeceksek bisikletli ulaşım... (Hilmi).

\section{Doğal Afetlerde Etkili Bir Şekilde Kullanılabilir}

Ayrıca bir doğal afet sonrasında ulaşılabilecek tek aracın bisiklet olabileceği de paylaşılan düşünceler arasındadır:

[...] Japonya depremi olduğunda yani tsunami olduğu zaman insanların binebilecekleri bisiklet dışında hiçbir şey yoktu. Onun dışında ben çok defa okudum 17 Ağustos 1999'da insanların ulaşabilecekleri hiçbir araç yoktu bisiklet dışında. Yani aslında bisiklet de bir kaos aracı. Bir kaosta kullanılabilen tek araç... (Hilmi).

\section{Ekonomik ve Çevre Dostu Bir Araç}

Yakıta ihtiyaç duymayan bir araç olması nedeniyle bisikletin hem ekonomik hem de çevreci olduğu aktarılmıştır:

[...]İkinci sırada ekonomik kazancı geliyor. Yani ben bütün bu ulaştığım yerlere otobüsle, dolmuşla ya da taksiyle falan, yani zaten rotalarım taksiye izin veriyor daha çok yani otobüsle ya da taksiyle gidecek olsam ayda ortalama 450-500 lira para harcamam gerekecek. Bu paranın çoğu cebimde yani (Çiçek).

[...]Çevresel kirlilik yaratmiyorsunuz; gürültü ,ses ve hava kirliliği gibi. Bütünüyle kendi eforunuzla bir yerden bir yere ulaşlyorsunuz... Yakıt fiyatlarl düşünüldügüunde son derece ekonomik. Tamamen kendi gücünüzle gidiyorsunuz (Oğuz).

\section{Sağlıklı Yaşam Anahtarı}

Bisiklet kullanmanın sağlıklı bir yaşam sürebilmek adına avantaj yarattığı da katılımcılar tarafindan vurgulanan noktalar arasındadır:

[...] İyi hissettiriyor yani, daha sağlıklu bir şey, daha mutlu oluyorsun 
bisiklet kullanınca. Araba kullanırsan ya da toplu taşımda geriliyorsun; stres yükleniyorsun. Bisiklet kullaninca daha mutlu oluyorum yani, kendimi daha iyi hissediyorum okula da gitsem, eve de gitsem (Tolga).

[...] Vücudumdaki birçok şeyin daha faydalı çalıştığını, daha düzgün çalıştı̆̆ını, daha enerjik olduğunu hissediyorum kendimin. Yani hiçbir ilaç kullanmıyorum; hiçbir hastalığım yok. Ama sanki emekliliğime evde otursaydım, bisiklete binmeseydim sanki böyle olmayacaktı gibi geliyor bana ki büyük etken yani, bisiklete binmem çok büyük etken. Çok săglıklıyım; bisiklete borçluyum bu sağhlklı olmamı da (Gül).

Yapılan analizler sonucunda katılımcılar için kent yaşamında bisiklet kullanmanın avantajlarına ilişkin oluşturulan şema aşağıda gösterilmiştir.

\section{Kent Yaşamında Bisiklet Kullanmanın Dezavantajları}

Katılımcımlar Ankara ilinde bisiklet kullanmanın dezavantajlarının avantajları yanında çok daha az olduğunu belirtmişlerdir. İfade edilen dezavantajlarınsa mevcut sorunlarla örtüştüğü görülmektedir. Özellikle yoğun kent trafiği, bu yoğunluğun yarattığı çevresel sorunlar ve motorlu araç sürücülerinin olumsuz davranışlarının bisiklet kullanımı açısında ciddi dezavantajlar oluşturduğu katılımcılar tarafından ifade edilmiştir:

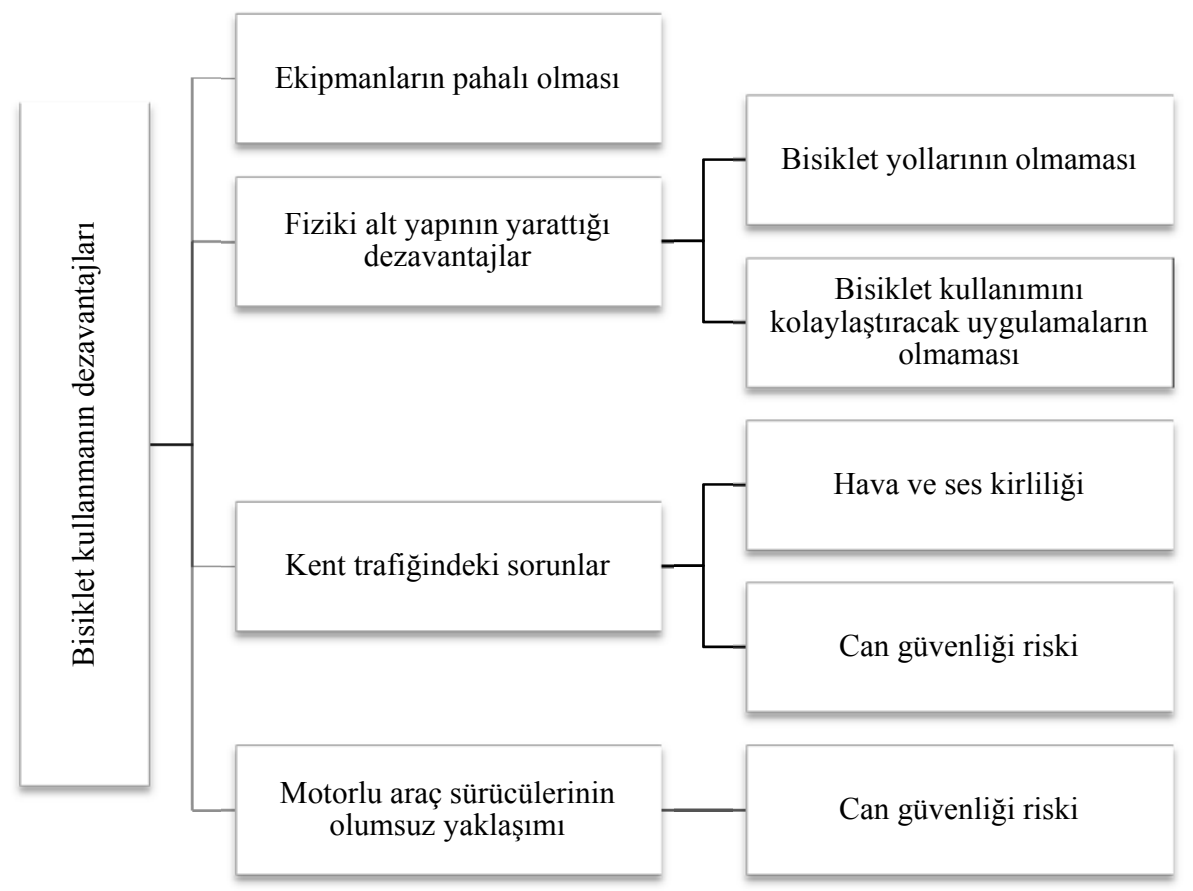

Fig. 4. Kent Yaşamında Bisiklet Kullanmanın Dezavantajları

[...] Eğer trafiğin yoğun olduğu saatlerde o araç trafiğinin hemen yanı başında bisikletinize biniyorsanız, hava kirliliğinden, gürültüden olumsuz etkileniyorsunuz. Tabi araçların yarattığ tehlikeleri en başa koyabiliriz bu noktada. Yani trafiğin sizi yok sayarak şu anda akiyor olmastnın getirdiği bir takım tehlikeler var. Bazen bisikletçiler biraz kelle koltukta tabir edebileceğimiz şekilde de gidebiliyorlar ve bunun sonuçlarını maalesef son birkaç yıldır kent içinde yaşanan bisiklet kazaları, kaza 
demeye çok dilim varmıyor. Bilinçsiz sürücülerin çeşitli yöntemlerle kazalara yol açarak, bisikletçileri işte öldürmesinde de gördük bu güne kadar. Yani en büyük dezavantaj aslında araç trafiğinden kaynaklanan, onun dışında bir dezavantaj göremiyorum (Oğuz).

[...] Sürücülerin bize saygısıllığı, özellikle bu minibüs sürücülerinin, otobüslerin, özellikle belediye otobüslerinden çok çok sıkıntımız, çok mustaribiz, çok sıkıntımız var. Sıkıştırıyor, arkamızdan gelirken sessizce yanaşıp işte yanımızdan hızla geçmeleri, ondan sonra minibüs şoförlerinin bizi hiç hiçe saymaları hatta çok önemli bir anım var onu da anlatayım. Arkada kalmış bir grubu beklerken, minibüs şoförü sağa çekmiş bekliyor. Dolayısıyla ben de sağda grubumu bekliyorum. Minibüs şoförü ile küçük bir muhabbetimiz oldu. Adam bana şöyle yaklaştı: "Ya aklınız mı yok sizin, niye bu saatte bu gece vakti niye bu havada dışarıda dolaşlyorsunuz? Sizleri görünce ben sinirleniyorum. Sinek gibi ezmek istiyorum" gibi bir laf etti. Aklım durdu yani (Gül).

[...] Trafikte çok büyük tehlikeye giriyoruz. Yani trafik aslinda, en büyük dezavantajı trafik; yoğun olması. Insanların işte duyarsız olmasından dolayı. Yani şöyle ben senelerdir doğa sporlarılla uğraşan birisi olarak tabi bunu hep dile getiriyorum ama biraz da tecrübem de var. On senedir doğaya, dă̆a gidiyorum; inan ki dă̆da yaşadĭ̆ım hani tehlikeler, şehirde bisiklet binmenin yanında solda sifir kalıyor. Gerçekten bisiklete binmek dăğn zirvesine tırmanmaktan daha tehlikeli Ankara ilinde (Hakan).

Ayrıca bisikletin ve ekipmanlarının pahalı olmasının olumsuzluklar arasında olduğu belirtilmiştir.

[...] Aslinda bisiklet kullanmak yani ucuz gibi görünüyor da bisiklet falan pahal yani memlekette. Bisiklet pahal, aksesuarlar, ekipmanlart pahalı. Ne bileyim işte şey var, çok yaygıı değil. Mă̆aza sayısı falan az. Insanların çoğu yurt dı̧̧ııdan alışveriş yapıyor mesela istediği şeyleri bulamiyor burada ya da pahalı oluyor (Tolga).

Kentte bisiklet kullanımının başlıca sorunları arasında yer alan fiziki sorunların yarattığ olumsuzlukların da dezavantajlar arasında gösterilebileceği Oktay isimli katılımcının ifadesinden anlaşılmaktadır:

[...] Fiziksel olarak bisiklet kullanmaya uygun yolların olmaması büyük bir dezavantaj. Tabi bu da bizim yapabileceğimiz bir şey değil. Yerel yönetimlerin yapması gereken bir şey. Maalesef bu yönüyle Ankara çok şanssız bir kent. Çünkü hiçbir belediye bisiklet yolu yapımı konusunda bir adım atmads (Oktay).

Yapılan analizler sonucunda katılımcılar için kent yaşamında bisiklet kullanmanın dezavantajlarına ilişkin oluşturulan şema aşağıda gösterilmiştir.

\section{Kent Trafiğinde Birey Bisiklet Kullanırken Kendini Güvende Hissediyor Mu?}

Katılımcılar "Kent trafiğinde bisiklet kullanırken kendinizi güvende hissediyor musunuz?" sorusuna olumsuz yanıt vermişlerdir. Ancak güvende hissetmemenin bisiklet kullanımına engel olmadığı Çiçek isimli katılımcı tarafından ifade edilmiştir: 


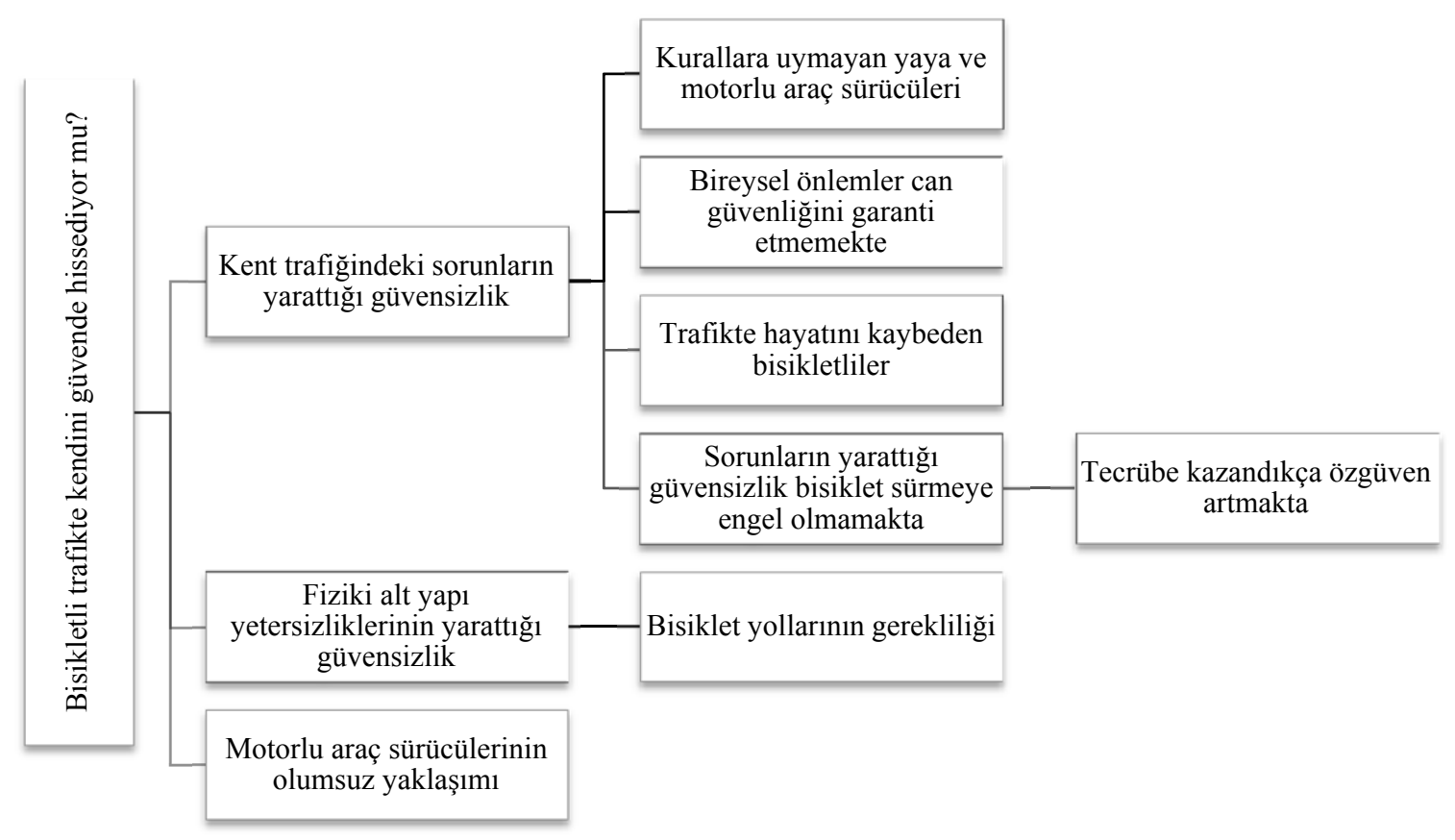

Fig. 5. Bisikletli Trafikte Kendini Güvende Hissediyor Mu?

[...] Göze aldım diyelim. Tehlikelerin bilincindeyim; farkındayım aslında güvenli değil bunu çok iyi biliyorum ama göze aldım ve hani normal bir sürücü bir kez dikkat ediyorsa, ben on kez dikkat ederek hareket etmeye çalışıyorum (Çiçek).

Özellikle Ankara'da kent trafiğinde hayatını kaybeden bisikletlilerin olması nedeniyle, bisiklet kullanıcılarının kendilerini hiçbir şekilde güvende hissetmedikleri görülmektedir:

[...] Yol alırken sürekli kendinizi saknnarak bisiklet sürmeniz zorunluluğu var. Fakat bu da her zaman mümkün olamıyor. Yani sakınsanız da hiç ummadığınız yerden her türlü tedbiri almış olsanız, ışıklandırmanız, aynanız, her türlü güvenlik donanımını yapsanız bile; o bilinç olmadı̆̆ için hiç beklemediğiniz bir anda bir kazaya kurban gitme ihtimaliniz oldukça yüksek ne yazık ki (Oğuz).

[...] Bizim başladiğımız tarihten bu tarihe kadar nereden baksanız on tane arkadaşımızı kaybettik; bunların çoğu da Ankara'da. Çoğu da sürücülerin hatalı olduğu kazalardl. Yani sürücüden kaynakll, bisiklet sürücüsünden kaynaklı hatalar değildi. En son işte bir tane arkadaşımızı kaybettik. Üç tane ışık, gecenin ikisi, reflektörlü yeleği, her şeyi var. Buna rağmen biz bu arkadaşımızı kaybettik. Yani ben daha ne yapayım? Elimden gelen her şeyi yaptım; ben üzerime düşeni yaptım; ben daha ne yapabilirim? Koskoca Konya Yolu ve gecenin ikisi. Dolaylsiyla yasalarda çok büyük bir boşluk var; insanlarımız çok bilinçsiz (Yasemin).

[...] Insanlar daha duyarl olduklarl zaman daha güvende hissedeceğiz.

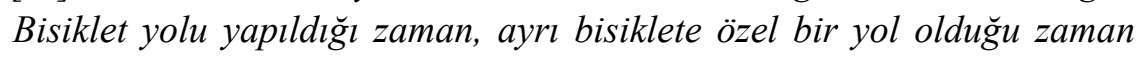
zaten güvende hissederiz. Ama şu anda trafiğin içerisinde bisiklete bi- 
niyorken böyle bir şey hani kimse için söz konusu değildir diye düşünüyorum (Hakan).

Şemsi isimli katılımcı grup halindeki sürüşlerin görünürlüğü artırdığını, yalnız bisiklet sürdüğü zamanlara göre daha güvende hissettiğini ifade etmiştir:

[...] Kalabalık kullanırken biraz daha güvende hissedebiliyorum çünkü görünürlügümüz artıyor. Ama tek başına ya da hani bir ya da iki kişiyle beraber pedal çevirirken aynı güveni sağlayamıyoruz ya da aynı güveni hissedemiyoruz ne yazık ki. Tabi ki can güvenliği anlamında. Yani yol hakkı bizdeyken bile araçların bize küfür etmelerine tanık oluyoruz. Korna çalmalar ya da çeşitli tacizlerine tanık oluyoruz; bunları yaşıyoruz ve ciddi problemlerimiz var bu konuda. Bunların da yine eğitimle alakalı olan şeyler olduğunu düşünüyorum (Şemsi).

Yapılan analizler sonucunda katılımcıların kent yaşamında bisiklet kullanırken kendilerini güvende hissedip hissetmediklerine ilişkin oluşturulan şema aşağıda gösterilmiştir.

\section{Sorunların Çözümü İçin Neler Yapılabilir?}

Katılımcılar Ankara'da kent yaşamında bisiklet kullanımının önündeki sorunların çözümü noktasındaki önceliğin fiziki alt yapı problemlerinin çözümü olarak görmektedir.

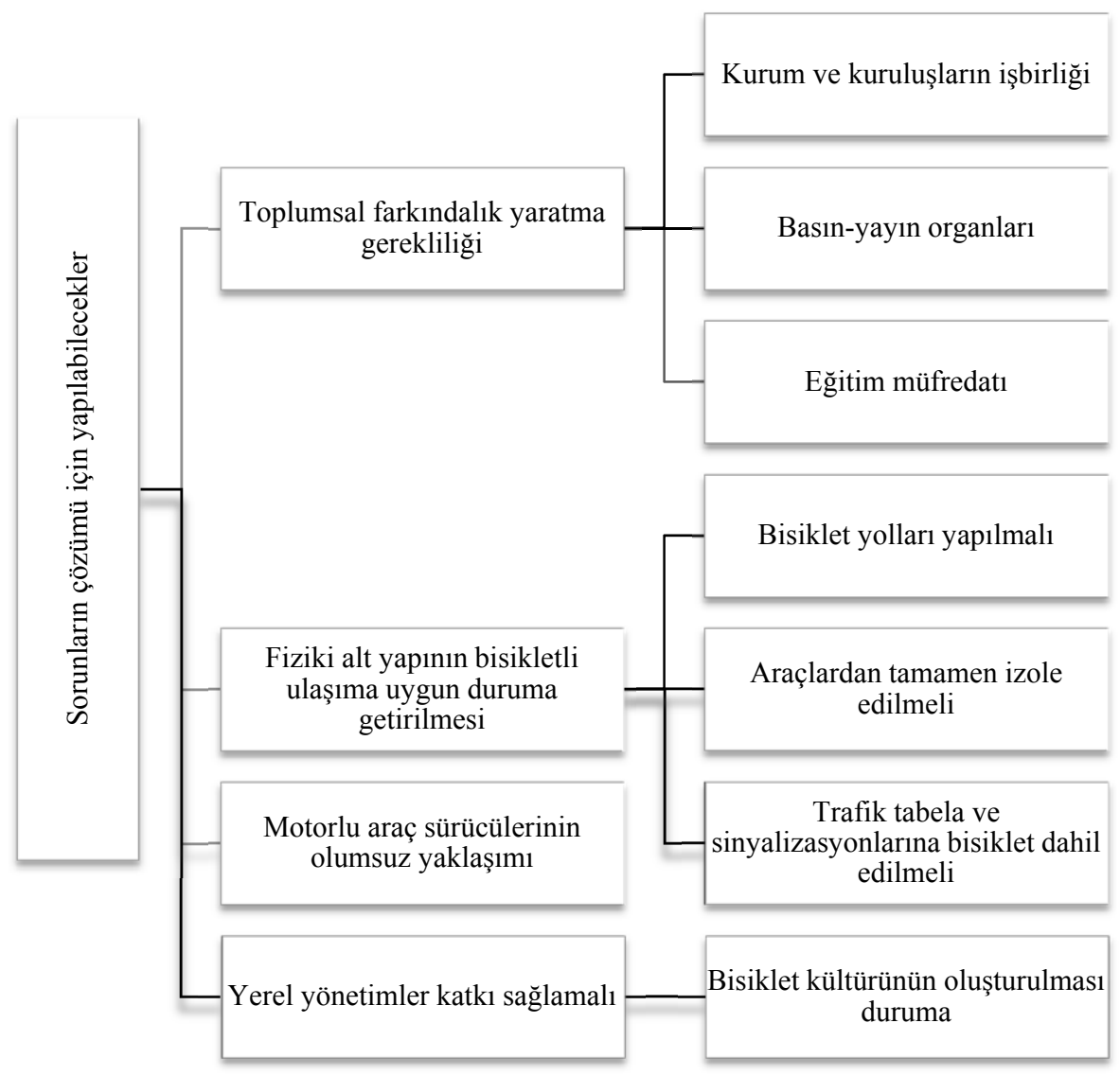

Fig. 6. Sorunların Çözümü Iç̧in Yapılabilecekler

[...]Bisiklet yolu yapılmalı ve düzgün yapılmalı yani dediğimiz gibi bir 
çizgiyle bırakılmamall ya da tek bir şerit bırakılmamalı. Yanına bir taş koyulmalı ki bir arabanin oraya park etmemesi veya oraya girmemesi. Hatta çok fazla reflektör koyulmalı bisikletçi için. Çünkü o an lambanın olmadiğı bir yer olur; en azından kendi feneri ile o reflektörü görebilir dönüslerde filan (Ali).

[...]Trafikle ilgili gerekli uyarıların özellikle yollara konulmasl gerekli. Mesela yollarda diğer uyarl işaretlerinin yanlarına ya da hani bunun gibi uyarılar olarak sinyalizasyonlara bisiklete bir buçuk metreden fazla yaklaşılmaması gerektiği ile ilgili uyarılar konulabilir yollara. Ya da bu yolda bisikletliler de var diye çeşitli tabelalar konulabilir (Şemsi).

[...]Bisiklet yolları kesinlikle araç yollarından kaldırımlarla ayrılmalı çünkü bir çocuk öldüğü zaman okuluna giderken ve aileler bunu gördügü zaman, kimse bisiklete binmeyecek (Hilmi).

[...] Ne yapılacağı belli. Basit şeylere, toplu taşımaya bisiklet sokacaksin; bisiklet parklarl yapacaksın; uygun yerlere bisiklet yolları yapacaksin; bisiklet kiralama sistemleri yapacaksin (Tolga).

Ayrıca toplumda bisiklet kültürünün oluşturulabilmesi için farkındalık çalışmaları yapılmasının etkili olacağ katılımcılar tarafından aktarılmıştır:

[...] Bisiklet kültürünü yerleştirmek lazım. Bisiklet kültürünün yerleşmesi, gelişmesi için kimlere görev düşüyor; en başta hani kent kültüründen sorumlu bir kent kültüründen sorumlu olan kurum hangisidir; belediyedir. Ulaşımdan sorumlu belediyeler hatta tek belediye değil de, hem büyük şehir hem ilçe belediyeleri. Onların bir şey yapması lazım (Tolga).

[...] Dolayısıla bizim görevimiz bisikletliler olarak bisiklete binen kişileri eğitmek; onlara bisiklet kültürünü aşılamak. Ama sizin göreviniz ne; yani ülke olarak söylüyorum meclistekilerin görevi de yasalara bir kere bisikletin yerini yeniden çerçevelendirmek. Kanunları katılaştırmak ve insanlarda bisiklete dair algıyı artırmak için kamu spotları yap. Billboardlara her şeyi koymayı biliyoruz; bütün reklamları. Bir haftanı da şeye ayır; bisikletliye dikkat diye ayır (Yasemin).

Bu problemlerin çözümü aşamasında atılacak adımların bir bütün olarak ele alınmasının gerekliliği ve uluslararası standartlarda uygulamalar olması gerektiği Oğuz isimli katılımcı tarafindan ifade edilmiştir:

[...] Bence sorun böyle parça bölük önlemlerle değil, bir bütün olarak baştan ele alınmal. Yani Ankara'nın ulaşım planı yapılırken, şu anda herhalde yapılma aşamasında diye duyuyoruz ana ulaşım planı; bunun içerisine bisiklet mutlaka iyi bir şekilde bir unsur olarak, ana unsurlardan biri olarak konmall. Ve bunun için ilgili bütün kuruluşlar işbirliği yapmall. Yani yerel yönetimler, merkezi yönetimler, sivil toplum kuruluşlarl, bisikletle ilgili kuruluşlar, üniversiteler bunla işbirliği yapıp, temelde Ankara'da bisiklet yollarının yapılabileceği, uygun olan her alanı güzel bir mastır planı şeklinde hazırlanmalı. Daha sonra bunun tabi alt yapısı, tabelaları, işaretleri vs. her şeyiyle uluslararası standartlarda ol- 
malı bu. Ve bununla beraber, buna paralel olarak insanlartn bisikleti bir ulaşım aracı olarak kabul etmesi için özellikle sürücülerin bu konuda bilinçlendirilmesi, farkındalık kampanyalarıyla dikkatlerinin çekilmesi çok önemli (Oğuz).

Yapılan analizler sonucunda sorunların çözümü noktasında neler yapılabileceğine dair katılımcıların önerilerine ilişkin oluşturulan şemada (Fig. 6) gösterilmiştir.

\section{Sonuç}

Türkiye'de bisiklet sürücülerinin başlıca sorunları; güvenli park yerlerinin olmayışı, toplumda yadırganmak, kentin coğrafi koşulları (dik eğimler), iklimin engel teşkil etmesidir (aşırı soğuk, aşırı sıcak, kar, buz, yağmur) (Uz \& Karaşahin 2004). Bir başka çalışmada bisiklet kullanımına yönelik engeller benzer şekilde; çevresel ve bireysel engeller olarak belirlenmiştir. Çevresel faktörler; fiziki engeller (yoğun trafik, güvenli park yerlerinin olmaması, yol bozuklukları vb.), iklim ve çevrenin yarattığı engeller, sosyal engeller olarak; bireysel faktörler ise; psikolojik, bilişsel ve duygusal engeller olarak belirlenmiştir (Kienteka, Rech, Fermino \& Reis 2012). Bu bağlamda bu çalışma tespit edilmiş olan bu sorunları doğrular niteliktedir. Ayrıca derinlemesine yapılan görüşmelerle Ankara özelinde farklı sorunlar da olduğu ve mevcut sorunların ve çözüm önerilerinin ise daha detaylı bir şekilde ele alındığı görülmektedir.

Yerel yönetimlerin bu sorunları gidermek adına bisikletli ulaşım ile ilgili fiziki çalışmalara ve alt yapı çalışmalarına önem vermemesi; kentlerde ulaşımın ağırlıklı olarak motorlu araçlarla sağlanmasına neden olmaktadır. Kentlerdeki ulaşım sorununu çözmek savıyla yapılan yeni motorlu araç yolları; trafik sıkışıklığına çözüm olamadığı gibi, hava ve gürültü kirliliğinin de kabul edilemez sınırlara yaklaşması gibi olumsuz sonuçlar doğurmaktadır (Uz \& Karaşahin, 2004). Ayrıca kentin hızlı trafiğinde motorlu araç sürücüleri tarafindan zaman zaman dikkatsizce yapılan hatalar ve hatta kasten yapılan olumsuz davranışlar sonucunda bisiklet sürücüleri trafikte hayatını kaybetmektedir (Hürriyet Gazetesi 2014; Radikal Gazetesi 2013; Hürriyet Gazetesi 2013).

Bisiklet sürücüsünün güvenli bir şekilde seyahat edebilmesi için motorlu araçlardan izole edilmiş güvenli bisiklet yolları ve sinyalizasyon sistemleri oluşturulması da sorunların çözümü noktasında önem teşkil etmektedir. Ayrıca "kültürel ve ekonomik boyutlart içeren bilgilendirme, eğitim ve trafik yönetimi, denetimi ve işletilmesi alanlarında bir bütün olarak gelişstirilecek, kapsamlı ve çok boyutlu planlar çerçevesinde" (Uz \& Karaşahin 2004) bisiklet kullanımının yaygınlaşacağı düşünülmektedir.

Araştırmanın sınırlılıklarından bir tanesi, örneklem grubunun bisiklet kullanan bireylerden oluşmasıdır. İleride yapılacak çalışmalarda kent yaşamında bisiklet kullanmayan bireylerin kullanmama nedenlerinin araştırılmasının, bisiklet kullanımına engel teşkil eden konulara farklı bir bakış açısı kazandırabileceği düşünülmektedir.

Araştırma, uygulamaya yönelik bir takım önerileri de gündeme getirmiştir. Gündelik yaşamında bisiklet kullanan bireylerin yaşamındaki değişiklikler, bireylerin bisiklet kullanabilmesi için sunulan olanakların artırılmasının önemini vurgulamaktadır. Türkiye'de bireylerin fiziksel aktivite ve spora katılımının azlığı ve mevcut enerji kaynakları açısından dışa bağımlı bir ülke olduğumuz düşünüldügünde, bireyleri bisiklet kullanmaya teşvik edecek özel projelerin geliştirilmesi öncelikli alanlardan birisi olmalıdır. 


\section{KAYNAKÇA}

Akay A. (2006). Ulaşımda Bisikletin Yeri ve Ankara Bilkent Koridorunda Bisiklet Yolu Önerisi. Yüksek Lisans Tezi. Gazi Üniversitesi, Fen Bilimleri Enstitüsü, Ankara 2006.

Ardahan F. \& Lapa T. Y. (2011). “Açık Alan Rekreasyonu: Bisiklet kullanıcıları ve Yürüyüşçülerin Doğa Sporu Yapma Nedenleri ve Elde Ettikleri Faydalar”. Uluslararasi Insan Bilimleri Dergisi 8/1 13271341.

Ardahan F. \& Mert M. (2014). "Bireyleri Bisiklet Kullanmaya Motive Eden Faktörler Ölçeğinin Geliştirilmesi ve Türk Popülasyonu İçin Güvenirlilik Geçerlilik Çalışması”. Akademik Sosyal Araştırmalar Dergisi 2/1 (2014) 409-427.

Arpınar-Avşar P. (2009). Bisiklet ve Sürücü Üzerine Titreşim İletimi: Alan ve Laboratuvar Çalışması. Doktora Tezi. Orta Doğu Teknik Üniversitesi, Beden Eğitimi ve Spor Bölümü, Ankara 2009.

Broache A. (2012). Perspectives on Seattle Women's Decisions to Bike for Transportation. Post-Graduate Thesis. University of Washington, Department of Urban Design and Planning, Seattle, WA 2012.

Buehler R., Pucher J. (2012). "Walking and Cycling in Western Europe and the United States: Trends, Policies, and Lessons". TR News (2012) 280.

Daley M., Rissel C. (2011)." Perspectives and Images of Cycling As a Barrier or Facilitator of Cycling”. Transport Policy 18 (2011) 211-216.

Elbeyli Ş. (2012). Kent İçi Ulaşımda Bisikletin Konumu ve Şehirler İçin Bisiklet Ulaşımı Planlaması: Sakarya Örneği. Yüksek Lisans Tezi. İstanbul Teknik Üniversitesi, Fen Bilimleri Enstitüsü, İstanbul 2012.

Huy C., Becker S., Gomolinsky U., Klein T. \& Thiel A. (2008). "Health, Medical Risk Factors, and Bicycle Use in Everyday Life in the Over-50 Population". Journal of Aging \& Physical Activity 16/4 454-464.

Hürriyet Gazetesi. (2013, Ağustos 12). Trafik Canavarı Emniyet Tanımadı. Kaynak: http://www.hurriyet.com.tr/ankara/24498648.asp. Erişim tarihi:14.12.2014.

Hürriyet Gazetesi. (2014, Temmuz 10). Demir Atında Can Verdi. Kaynak: http://www.hurriyet.com.tr/ ankara/26765352.asp. Erişim tarihi:14.12.2014.

İyinam Ş. \& İyinam A. F. (1999). “Kent İçi Ulaşımında Bisiklet Kullanımı”. II. Ulusal Kentsel Altyapı Sempozyum Kitabı (1999) 109-115.

Kienteka M., Rech C. R., Fermino R. C., Reis R. S. (2012). "Validity and Reliability of an İnstrument to Measure Barriers to Bike Use in Adults". Brazilian Journal of Kinanthropometry and Human Performance 14/6 (2012) 624-635.

Krizek K. J., Poindexter G., Barnes G. \& Mogush P. (2007). "Analysing the Benefits and Costs of Bicycle Facilities. Via Online Guidelines". Planning, Practice \& Research 22/2 (2007) 197-213.

Lin J. R., Yang T. H. \& Chang Y. C. (2013). “A Hublocation Inventory Model for Bicycle Sharing System Design: Formulation and Solution”. Computers \& Industrial Engineering 65/1 (2013) 77-86.

Marshall C., \& Rossman G. B. (2006). Designing Qualitative Research. London 2006.

Mert K. \& Öcalır E. V. (2010). "Konya'da Bisiklet Ulaşımı: Planlama ve Uygulama Süreçlerinin Karşılaştırılması". METU Journal of the Faculty of Architecture 27/1 (2010) 223-240.

O’brien O., Cheshire J. \& Batty M. (2013). "Mining Bicycle Sharing Data for Generating Insights Into Sustainable Transport Systems". Journal of Transport Geography 34 (2013) 262-273.

Radikal Gazetesi. (2013, Temmuz 29). ODTÜ Meril İçin Ağladı, Bisiklet İçin Eylem Yaptı.

Kaynak:http://www.radikal.com.tr/turkiye/odtu_meril_icin_agladi_bisiklet_icin_eylem_yapti-1143873. Erişim tarihi:14.12.2014.

Shaw L., Poulos R. G., Hatfield J., Rissel C. (2015). "Transport Cyclists and Road Rules: What Influences the Decisions They Make?”. Inj Prev 21 (2015) 91-97. Doi:10.1136/Injuryprev-2014041243.

Süme M. \& Özsoy S. (2010). “Osmanlı'dan günümüze Türkiye'de Bisiklet Sporu”. Selçuk Üniversitesi Sosyal Bilimler Enstitüsü Dergisi 24 (2010) 345-360. 
Tomlinson D. (2003). "The Bicycle and Urban Sustainability". FES Outstanding Graduate Student Paper Series 7/6 (2003) 1-32.

Uz V. E. \& Karaşahin M. (2004). "Kent İçi Ulaşımda Bisiklet". Türkiye Mühendislik Haberleri (TMH) 429/1 (2004) 41-46.

Yıldırım A., \& Şimşek H. $\left(2013^{9}\right)$. Sosyal Bilimlerde Nitel Araşstırma Yöntemleri. Ankara 2013. 
